\title{
Gambaran Kepatuhan Mahasiswa dalam Melaksanakan Protokol Pencegahan Covid-19 di Stikes Suaka Insan Banjarmasin
}

\author{
Theresia Jamini, Septi Machelia \\ Sekolah Tinggi Ilmu Kesehatan Suaka Insan Banjarmasin \\ Email : star.chra@gmail.com
}

\begin{abstract}
Abstrak
Virus Corona (Covid-19) merupakan penyakit yang menular melalui droplet dan aerosol yang mengandung virus SARS-CoV-2. Menjadi masalah bagi seluruh dunia bahkan di Kalimatan Selatan karena penyebarannya yang semakin hari semakin bertambah terlihat dari meningkatnya angka positif Covid-19. Di Kampus Stikes Suaka Insan Banjarmasin peneliti mengamati bahwa kepatuhan mahasiswa dalam melaksanakan protokol pencegahan perlu terus dijalankan dan ditingkatkan. Tujuan Penelitian ini adalah untuk mengetahui gambaran kepatuhan mahasiswa Stikes Suaka Insan Banjarmasin dalam melaksanakan protokol pencegahan Covid-19. Jenis Penelitian menggunakan penelitian kuantitatif dengan responden penelitian sebanyak 38 mahasiswa Stikes Suaka Insan Banjarmasin. Metode pengumpulan data menggunakan kuesioner yang diisi melalui google form. Data dianalisis menggunakan rumus distribusi frekuensi. Hasil penelitian menunjukkan bahwa dari 38 mahasiswa yang menjadi responden sebanyak 35 mahasiswa (92,10\%) Patuh, 3 mahasiswa (7,90\%) Tidak Patuh. Dari hasil penelitian didapat ditarik kesimpulan bahwa mahasiswa Stikes Suaka Insan Banjarmasin mayoritas patuh dalam melaksanakan protokol pencegahan covid19.
\end{abstract}

Kata Kunci : Kepatuhan, Protokol Pencegahan Covid-19.

\section{Pendahuluan}

Corona merupakan virus yang menjadi perhatian seluruh dunia termasuk Indonesia di mana penyebaran virus ini sangat cepat dan corona viruses $(\mathrm{CoV})$ menyebabkan penyakit mulai dari Flu hingga penyakit yang lebih berat seperti Midlle East Respriatory syndrom (MERS-CoV) dan Servere Acute Respriatory syndrom (SARS-CoV). Gejala yang ditimbulkan meliputi batuk demam, letih, sesak napas dan penurunan nafsu makan. Penyebaran covid dapat menjadi ancaman kesehatan secara global di mana sejak virus corona (Covid-19) masuk dan melanda Indonesia. Jumlah kasus positif pun terus mengalami peningkatan yang signifikan bahkan menelan korban jiwa (WHO, 2020).

Ratusan ribu orang telah terinfeksi, ribuan orang meninggal dunia, dan jutaan orang telah merasakan dampak negatif dari wabah tersebut.Pemerintah telah melakukan berbagai upaya mengatasi penularan virus ini, baik pencegahan maupun penanganan korban terinfeksi namun belum mampu meredam penyebaran wabah Covid-19 (WHO, 2020)

Pencegahan penyebaran virus Corona pun gencar dilakukan bukan hanya di indonesia tetapi dunia. Pemerintah masing-masing negara pun mulai mengeluarkan kebijakan-kebijakan untuk memutus rantai penyebaran covid-19. Di mulai dari kegiatan pabrik, industri, pendidikan, perkantoran, kegiatan sosial, budaya, ekonomi, politik hingga kegiatan keagamaan yang dilakukan terbatas dan lakukan di rumah. Namun, kendala utama yang menjadi permasalahan dalam upaya penanganan wabah Covid-19 adalah kurangnya kesadaraan masyarakat baik kalangan umum maupun mahasiswa. (Tuwu, Darmin, 2020).

Direktur Jenderal Pendidikan Tinggi Kementerian Pendidikan dan Kebudayaan pun menyebutkan bahwa ada 123 mahasiswa terkonfirmasi Covid-19 setelah melakukan unjuk rasa tersebut Sehingga akibat ketidakpatuhan mahasiswa menambah angka positif Covid-19 yang juga membuat sebagian anggota keluarganya juga terpapar Covid-19. Di Cilandak, Jakarta Selatan pun mahasiswa menjadi bagian dari penyebar Covid-19 yaitu 200 orang mahasiswa Institut Perguruan Tinggi Ilmu Alquran (PTIQ) terpapar 
covid-19 karena ketika mengikuti kuliah tatap muka dan ketika berada di lingkungan kampus mereka tidak mematuhi protokol kesehatan khususnya himbauan untuk menjaga jarak. Berdasarkan penelitian lham Syahrul Jiwandono, dkk universitas Mataram. Jumlah mahasiswa yang merasa sudah memahami protokol kesehatan Covid-19 adalah 24\% (82 mahasiswa). Sedangkan 36\% (93 mahasiwa) masih ragu terhadap pemahamanya. Terakhir terdapat 40\% (105 mahasiswa) merasa belum memiliki pemahaman terkait protokol kesehatan Covid-19. Secara garis besar, masih banyak mahasiswa yang belum memahami bagaimana menerapkan protokol Kesehatan Covid-19. Hal ini berdampak pada ketidakpatuhan mahasiwa dalam menjalankan protokol kesehatan.

Berdasarkan Riset ULM (Uiversitas Lambung Mangkurat) yang dilakukan oleh Tim pakar percepatan gugus tugas covid-19 secara daring, yaitu dengan menggunakan fitur google form yang disebar melalui platform sosial media dari tanggal 17 Juli sampai 8 Agustus 2020. Selama kurun waktu tiga minggu jumlah partisipan yang mengisi survei ini ialah 642 orang. yang mana 75,2\%-nya berada di rentang usia 21-50 tahun. Jumlah partisipan perempuan $(60,90 \%)$ yang mengisi survei ini lebih banyak dibandingkan partisipan laki-laki $(39,10 \%)$. Sebanyak $77,10 \%$ dari jumlah partisipan adalah masyarakat yang tinggal di perkotaan, sementara $22,90 \%$ adalah masyarakat pedesaan.

Partisipan yang mengisi survei ini rata-rata adalah pekerja $(48,90 \%)$, mahasiswa $(41,70 \%)$ dan lainnya $(9,40 \%)$. Hasil riset ini menunjukkan bahwa dari 14 perilaku kepatuhan yang diukur; perilaku memakai masker (88\%), menerapkan pola hidup sehat (65\%) dan menjaga jarak (59\%) adalah tiga perilaku kepatuhan tertinggi yang dilakukan oleh semua orang pada lintas usia. Sementara melakukan aktivitas fisik rutin 30 menit (14\%), menjaga kebersihan rumah (24\%) dan menjaga imunitas tubuh dengan mengonsumsi vitamin/suplemen (32\%). Dari hasil riset di atas bahwa mahasiswa yang mengisi fitur Google form yaitu $41,7 \%$ dan di peroleh ada 22\% Mahasiswa yang tidak taat atau patuh terhadap protokol kesehatan Covid19 dan itu juga dapat dilihat masih banyak kerumunan muda-mudi atau mahasiswa di kota banjarmasin baik di cafe-cafe, Transmart dan Duta Mall.

Berdasarkan studi pendahuluan terhadap 20 mahasiswa yang pada hari tersebut melakukan pembelajaran praktikum ofline. Hasil pengamatan yang peneliti peroleh adalah sebanyak 16 Orang mahasiswa tidak mematuhi protokol kesehatan dengan baik dan benar. sebanyak 18 mahasiswa tidak mencuci tangan dengan air kran yang disediakan di depan pintu masuk kampus, 5 mahasiswa tidak memakai masker dengan benar, dan 11 mahasiswa tidak menjaga jarak. Sedangkan 4 Mahasiswa tampak melakukan protokol kesehatan dengan baik. Diantaranya 2 mahasiswa ini mencuci tangan dengan air kran yang tersedia di depan pintu masuk kampus, memakai masker dengan benar 2 orang menjaga jarak saat bertemu dengan teman-temannya.

Oleh sebab itu penelitian ini difokuskan pada tujuan penelitian yaitu untuk mengetahui Gambaran Kepatuhan Mahasiswa dalam melaksanakan Protokol Pencegahan Covid-19 Di Stikes Suaka Insan Banjarmasin.

\section{Metode Penelitian}

Jenis penelitian ini merupakan penelitian deskriptif kuantitatif yang mempunyai tujuan untuk mendeskripsikan suatu fenomena, peristiwa, gejala, dan kejadian yang terjadi secara faktual. Dengan menggunakan metode survey kuantitatif yang dilakukan menggunakan pembagian kuesioner melalui google form (Sugiyono, 2012). Pada penelitian ini digunakan untuk mendapatkan gambaran kepatuhan mahasiswa dalam melaksanakan protokol pencegahan covid-19. Populasi dalam penelitian ini adalah Mahasiswa Kesehatan Suaka Insan Banjarmasin berjumlah 38 orang.

Penelitian ini di lakukan di Stikes Suaka Insan dimulai pada bulan September 2020 - Maret 2021. Penelitian ini menggunakan kuesioner yang dibagikan melaluli google form, dibuat berdasarkan standar KEMKES 2020 berbentuk pernyataan tentang protokol Pencegahan Covid-19 dengan 11 item pernyataan. Kemudian yang akan diamati oleh peneliti yaitu tentang kepatuhan dari Responden dari 11 item pernyataan, Cara pengisian kuesioner dengan memberi tanda ceklis $(\sqrt{ })$ pada salah satu pilihan jawaban yang tersedia 
dari pernyataan yang berkaitan dengan kepatuhan Mahasiswa dalam Melaksanakan Protokol Pencegahan Covid-19. Uji valid yang digunakan $\mathrm{r}$ table $=0,05$ derajat kebebasan $(\mathrm{dk}=\mathrm{n}-2)$ mengetahui nilai korelasi tiap pertanyaan signifikan maka akan dilihat pada tabel nilai product moment. Jika nilai $\mathrm{r}$ hitung $\geq \mathrm{r}(0,444)$ sampel tabel berarti valid demikian sebaliknya jika nilai $r$ hitungnya $\leq(0,444)$ sampel tabel tidak valid. Uji rehabilitasi Suatu konstruk atau reliabel jika memberikan nilai Cronbach Alpha >0.60. (Hidayat 2014 $\&$ Sugiyono, 2017).

Penelitian ini menggunakan analisis data univariat yang terdiri dari usia, jenis kelamin, Data dianalisis menggunakan tabel distribusi frekuensi. Sebanyak 38 responden yang dilibatkan dalam penelitian ini dan mengisi kuesioner melalui link google form yang disebarkan melalui grup Whatsapp dengan sebelumnya memberikan pernyataan kesediaan terlebih dahulu dengan cara menekan tombol persetujuan menjadi responden.

\section{Hasil Penelitian}

Hasil Penelitian "Gambaran Kepatuhan Mahasiswa dalam Melaksanakan Protokol Pencegahan Covid-19 Stikes Suaka Insan Banjarmasin” disajikan pada Tabel 1.

Tabel 1. Distribusi Frekuensi Kepatuhan Mahasiswa dalam Melaksanakan Protokol Pencegahan Covid19 di Stikes Suaka Insan Banjarmasin

\begin{tabular}{llcc}
\hline Tingkat Kepatuhan & Frekuensi & $\begin{array}{c}\text { Persentase } \\
(\boldsymbol{\%})\end{array}$ \\
\hline 1. & Patuh & 35 & 92,10 \\
2. & Tidak patuh & 3 & 7,90 \\
\hline \multicolumn{2}{r}{ Jumlah } & $\mathbf{3 8}$ & $\mathbf{1 0 0}$ \\
\hline
\end{tabular}

Berdasarkan Tabel 1, tampak bahwa dari hasil kuesioner yang dibagikan melalui google form dari tanggal 25-27 Mei 2021 kepada mahasiswa Stikes Suaka Insan yang berjumlah 38 orang. Bahwa kepatuhan mahasiswa dalam melaksanakan protokol pencegahan covid-19 mayoritas pada kategori patuh yaitu sebanyak 35 responden $(92,10 \%)$ hasil ini menunjukkan bahwa mayoritas mahasiswa Stikes Suaka Insan Banjarmasin patuh dalam melaksanakan protokol pencegahan covid-19.

Dari hasil penelitian di dapat sebanyak 3 responden $(7,90 \%)$ masuk dalam kategori tidak patuh dalam melaksanakan protokol pencegahan covid-19, 2 responden yang tidak patuh berjenis kelamin Laki-laki, 1 responden berjenis kelamin Perempuan. Dan dari tabel penelitian responden patuh sebanyak 35 orang diantaranya 9 orang berjenis kelamin laki-laki dan 26 orang berjenis kelamin perempuan. Sehingga jenis kelamin juga mempengaruhi tingkat kepatuhan seseorang, ditemukan bahwa perempuan lebih banyak daripada laki-laki dalam mematuhi dan menerapkan protokol kesehatan. Data tersebut sesuai dengan artikel yang dipublikasi oleh Behavioral Science and Policy, New York University dan Yale University pada tahun 2020 bahwa perempuan lebih memperhatikan kesehatan diri sehingga lebih patuh terhadap protokol kesehatan dalam pencegahan COVID-19. Perempuan lebih patuh dalam menggunakan masker, menjaga hygiene, dan menjaga jarak.

\section{Pembahasan}

Dari beberapa poin penelitian mulai dari menjaga kebersihan tangan,mamakai masker dan menjaga jarak peneliti mendapatkan masih ada mahasiswa stikes suaka insan yang masih kurang dalam menjaga jarak. Dari hasil penelitian peneliti mendapat sebanyak 1 orang mahasiswa yang tidak patuh saat menjaga kebersihan tangan,1 orang mahasiwa tidak patuh dalam menggunakan masker dan ada 2 orang mahasiswa yang tidak patuh dalam menjaga jarak, dari hasil tersebut masih adanya mahasiwa yang kurang dalam melaksanakan protokol pencegahan covid-19 padahal hal yang utama dilakukan dalam mencegah covid19 dengan mematuhi protokol pencegahan covid-19 dan juga seperti yang kita ketahui mahasiswa stikes 
Suaka Insan Banjarmasin adalah mahasiwa kesehatan dan seharusnya lebih patuh dalam melaksanakan protokol pencegahan covid-19, dikarenakan mahasiwa tersebut pasti sudah mengetahui hal dari segi pengetahuan.

Dari hasil penelitin ada beberapa poin pembahasan dan peneliti mendapatkan responden yang tidak patuh berbeda-beda. Sehingga penulis menyimpulkan dari hasil penelitian responden yang tidak patuh berbeda-beda dari setiap poin pembahasan.

Berdasarkan hasil penelitian, maka menurut penulis Kepatuhan Mahasiswa Stikes Suaka Insan Banjarmasin perlu terus ditingkatkan atau dipertahankan bahkan kita bisa menjadi contoh dan ambil bagian dalam mengingatkan orang-orang yang ada disekitar kita terutama keluarga kita untuk melaksanakan protokol pencegahan Covid-19 dengan baik

Menurut Buana (2020) dijelaskan bahwa protokol kesehatan wajib diterapkan selama masa pandemi. Suni (2020) juga menjelaskan protokol kesehatan untuk penanggulangan COVID-19 terdiri dari fase pencegahan, fase deteksi dan fase respon. Sependapat dengan Buana dan Suni, Protokol kesehatan menjadi penting mengingat kita sudah memasuki era new normal pasca COVID-19. Sehingga Peran dari pemerintah dan juga kita sebagai mahasiswa Stikes Suaka Insan banjarmasin sangat dibutuhkan untuk mengurangi penularan yang lebih banyak. Kementerian Kesehatan RI (2020) juga mengeluarkan pedoman kesiapsiagaan dalam menghadapi penyebaran COVID-19. Upaya yang dapat dilakukan pada fase pencegahan oleh setiap individu antara lain: Memakai masker, Memakai sarung tangan, Menggunakan hand sanitizer/desinfektan, Mencuci tangan dengan sabun, Menghindari berjabat tangan, Menghindari pertemuan atau antrian Panjang, Menghindari menyentuh benda/permukaan benda di area publik, Menghindari naik transportasi umum, Menjaga jarak setidaknya dua meter dari orang lain ketika di luar rumah. Penyebaran COVID-19 dicegah dengan deteksi dini, yaitu isolasi, melakukan proteksi dasar seperti menjaga jarak minimal 2 meter, memperbanyak mencuci tangan dan menggunakan masker bila berada di area padat atau beresiko penularan (Howard dkk, 2020; Susilo dkk, 2020).

\section{Kesimpulan}

Gambaran kepatuhan Mahasiswa dalam melaksanakan Protokol Pencegahan Covid-19 di Stikes Suaka Insan Banjarmasin cenderung lebih patuh terhadap protokol pencegahan Covid-19 karena dari 38 mahasiswa, sebanyak $35(92,10 \%)$ mahasiswa patuh, sedangkan yang tidak patuh hanya $3(7,90 \%)$ mahasiswa.

\section{SARAN}

1. Bagi Mahasiswa Stikes Suaka Insan

Mahasiswa hendaknya aktif dalam melaksanakan protokol pencegahan covid-19 dengan mengutamakan 3M dalam kehudupan sehari-hari.

2. Bagi Dosen Pengajar

Diharapkan selalu memberikan contoh, dukungan dan motivasi kepada mahasiswa untuk selalu mematuhi dan melaksanakan protokol pencegahan covid-19.

3. Bagi Institusi Kesehatan/STIKES Suaka Insan

Diharapkan kampus lebih memperhatikan dan memberi pembatas disetiap tempat duduk agar mahasiswa tidak duduk berdekatan, dikarenakan hasil dari penelitian didapat masih ada mahasiswa yang tidak menjaga jarak.

4. Bagi peneliti selanjutnya

Diharapkan dapat digunakan sebagai data rujukan bagi peneliti yang akan datang dan dapat meneliti penelitian yang serupa seperti :

1) "Faktor-faktor yang mempengaruhi Pelaksanaan Protokol Pencegahan Covid-19" 
2) "Hubungan Tingkat Pengetahuan dengan Sikap dan Perilaku Mahasiswa terhadap pencegahan Infeksi Covid-19".

\section{Daftar Pustaka}

Ajzen, I. 1985. Attitude, personality and behaviour. Milton Keynes : Open University Press

Anik Sholikah., Eunike Raffy Rustiana, Ari Yuniastuti. 2017. "Faktor-faktor yang berhubungan dengan status Gizi di Perdesaan dan perkotaan "Public Health Perspective Journal 2 (1) (2017) 9-18

Anam Priyanto. 2014. 6 Langkah Mencuci Tangan Yang Benar Menurut WHO.

Arikunto, S. 2010. Prosedur Penelitian Suatu Pendekatan Praktik. Jakarta: Rineka Cipta.

Audric,A 2020. Penatalaksanaan Coronavirus Disease 2019 (Covid-19) www. alomedika.com/penyakitinfeksi.

Buana, D.R. 2020. Analisis Perilaku Masyarakat Indonesia dalam menghadapi Pandemi Virus Corona (Covid-19) dan kiat menjaga Kesejahteraan Jiwa.Salam : Jurnal Sosial dan Budaya Syar-i, 7(3), 217-226.

Brunner, \& Suddarth. 2013. Buku Ajar Keperawatan Medikal Bedah Edisi 8 Volume 2. Jakarta: EGC.

Depkes RI. 2005. Undang-Undang Republik Indonesia Nomor : 23 tahun 2005 Tentang Kesehatan; Hal 1. Fisioterapi Indonesia; Hal.5. Jakarta: Depkes.

Departemen Pendidikan Nasional 2008. Peraturan menteri Pendidikan nasional Tentang Standar Akademik dan Kompetensi Konselor.

http//www.bnspindonesia.org/document.php/id

Fakih. Mansur. 2013. Analisis Gender dan Transformasi Sosial. Yogyakarta : Pustaka PelajarGray Jhon, (1992), Men From Mars, Women From Venus.

Gugus Tugas Percepatan Penanganan Covid-19. 2020. Pedoman Penanganan Cepat Medis dan Kesehatan masyarakat Covid-19 di Indonesia. Jakarta

Gugus Tugas Penaganan Covid-19 ULM .2020. Covid19.ulm. ac.id

Hamzah, B. 2020. Gambaran Pengetahuan Dan Sikap Mahasiswa Kesehatan Tentang Upaya Pencegahan Penyebaran Covid-19. Vol 2 No 1. Bali Health Published Journal. Diakses tanggal 22 Oktober ; 15:47 PM. ejurnal. Stikesdamudayanan.ac.id

Howard. dkk. 2020. Face Maks Against COVID-19. Evindce Review. www.peprint.org

Hidayat, A. A. 2011. Metode Penelitian Keperawatan Teknik Analisis Data. Jakarta: Salemba Medika.

$\mathrm{Hu}, \mathrm{K}$. dkk. 2020. The adverse skin reactions of health care workes using ersonal protective equipment for COVID-19. Medicine, 2.

Hurlock, Elizabet. 2001. Psikologi Perkembangan Edisi Kelima . Jakarta : Erlangga

Kemenkes RI. 2020. Jaga Diri dan Keluarga Anda Dari virus Corona-Covid-19. Di akses tanggal 4 Maret 2020. www. kemnkes.go.id

Kamus Besar Bahasa Indonesia (Online). Di akses 11 November 2020 14:57 PM.

kbbi.kemendikbud.go.id/entri/

Kartini, K. 1989. Psikologi Abnormal dan Abnormalitas Seksual. Bandung : Mandar Maju

Koizer, B. G., Audrey, B., \& Shirlee, J. S. 2010. Buku Ajar Fundamental Keperawatan . Jakarta: EGC.

Majid, M. A., dan Istinah, U. 2011. Keperawatan Perioperatif. Yogyakarta: Gosyen. 
Muttaqin, A., dan Sari, K. 2009. Asuhan Keperawatan Perioperatif, Konsep, Proses, dan Aplikasi. Jakarta: Salemba Medika.

Niven, N. 2008. Psikologi Kesehatan : Pengantar Untuk Perawat dan Profesional. Jakarta: EGC.

Ni Putu Emy, I Made Arie, Gede Adi dan Ni Putu Dian. 2020. Gambaran Pengetahuan Masyarakat Tentang Covid-19 dan Perilaku Masyarakat di Masa Pandemi Covid-19. Jurnal Keperawatan Jiwa, 8 (3): 491-504. Diakses 23 Oktober 2020. 10.58. PM.

Notoatmodjo, S. 2003. Pendidikan dan Perilaku Kesehatan. Jakarta: Rineka Cipta.

Notoatmodjo, S. 2012. Promosi Kesehatan dan Perilaku Kesehatan. Jakarta: Rineka Cipta.

Notoatmodjo, S. 2014. Metodologi Penelitian Kesehatan. Jakarta: PT. Rineka Cipta.

Nursalam. 2013. Metodelogi Penelitian Ilmu Keperawatan. Jakarta: Salemba Medika.

Paramadina. 2007. Pengertian Gender. Retrieved on june 12, 2021 from http://paramadina.wordpress.com/2007/03/16.Pengertian-Gender

Permenkes No HK.07.01. 2020. Tentang Protokol Kesehatan bagi Masyarakat di Tempat dan Fasilitas Umum dalam Rangka Pencegahan dan Pengendalian Corona Virus Disease 2019 (COVID-19). Jakarta: Kementerian Kesehatan RI.

Pratita, N. D. 2012. Hubungan Dukungan Pasangan dan Health Locus of Control dengan Kepatuhan Dalam Menjalani Proses Pengobatan pada Penderita Diabetes Mellitus Tipe-2. Jurnal Ilmiah Mahasiswa Universitas Surabaya, 1 (1), Diakses tanggal 22 Maret 2020; 9:49 PM, http://journal.ubaya.ac.id/index.php/jimus/article/view/69.

Purwanti, Tetik Nurhayati. 2012. Analisis Faktor Dominan Yang Mempengaruhi Kepatuhan Pasien DM Tipe 2 Dalam Melakukan Perawatan Kaki. Jurnal Kesehatan, Vol. 10 No 1. 2017

Stanley, M. 2007. Buku Ajar Keperawatan Gerontik edisi: 2 . Jakarta : EGC

Sugiyono. 2012. Metode Penelitian Kuantitatif, Kualitatif, dan R \& D. Bandung: Alfabeta.

Sugiyono. 2013. Metode Penelitian Pendidikan Pendekatan Kuantitatif, Kualitatif, dan $R$ \& D. Bandung: Alfabeta

Sukesih, Usman, Setia B., dan Dian Nur A.S 2020. Pengetahuan Dan Sikap Mahasiswa Kesehatan Tentang Pencegahan Covid-19 Di Indonesia. Jurnal Ilmu Keperawatan dan Kebidanan, 11 (2): 258-264. Diakses tanggal 22 Oktober 2020; 22.48 PM.

Suni, N.S.P. 2020. Kesiapsiagaan Indonesia Menghadapi Potensi Penyebaran Corona. Pusat Penelitian Badan Keahlian DPR RI, XII.

Susisati M. 2008. Keterampilan Dasar keperawatan Paket 1. jakarta : Erlangga

Susilo, dkk. Adityo .2020. Coronavirus Disease 2019: Tinjauan Literatur Terkini. Jurnal Penyakit dalam Indonesia 7 (1)

Taylor, S.E. 2006. Health Psychology 6th Edition. New York : McGraw-Hill Inc

Tentama, F. 2018. Penarapan Perilaku Hidup Bersih dan Sehat (Phbs) Demi Kesejahteraan masyarakat Kecamatan Tuntang Kabupaten Semarang Jawa Tengah. Jurnal Pemberdayaan. Publikasi Hasi Pengabdian Kepada masyarakat, 1 (1), 13.https//doi.org/10.12928/jp.

Tuwu, Darmin. 2020. Dilema Penanganan Covid-19: Antara Legitimasi Pemerintah Dan Kepatuhan Masyarakat. Vol 1 No1. Jurnal Kesejahteraan dan pelayanan Sosial, 90-97 Diaskses tanggal 10 Oktober ; 10;12 PM, http://ojs.uho.ac.id

Thomas, B. 2010. Diakses tanggal 2 November 2020: 12.57.PM repository. iainpurwokerto.ac.id 
Umami, Z. 2010. Hubungan Antara dukungan Sosial dengan Kepatuhan Terhadap Aturan Pada Mahasiswa penghuni Ma'ad Sunan Ampel Al-AY di Universitasi Islam Negeri (UIN) Maulanan Malik Ibrahim Malang. Malang

UU RI No. 38. 2014. Undang-undang Republik Indonesia No.38 Tahun 2014 Tentang Keperawatan. Jakarta.

Wilujeng, A.P. 2010. Efektivitas Pelatihan Berpikir Posistif terhadap Kepatuhan pada aturan Santri Pondok Pesantren Tebuireng jombang. Malang

WHO. 2020. Rolling Updates On Coronavirus Disease (Covid-19). Diakses 4 Desember 2020: www.who.int

WHO. 2020. Coronavirus disease (COVID2019) situation reports.

https://www.who.int/docs/defaultsource/coronaviruse/situation-reports/20200418sitrep-89covid19.pdf?sfvrsn=3643dd38_2

WHO. 2020. Anjuran mengenai Penggunaan Masker dalam konteks COVID-19, World Health Organization . 1-13

Yusup, D. K., Badriyah, M. Suryandi, D. dan Asih, V.S. 2020. Pengaruh Bencana Covid-19, Pembatasan Sosial, dan Sistem Pemasaran Online terhadapa perubahan perilaku konsumen. Http://Digilib. Uinsgd. Ac.Id. I (1), 1-10. 